UDC 636.2.08./085.7.

\title{
THE INFLUENCE OF OPTIMAL DIET RECIPES INCLUDING COMPLEX DRUG DEVIVIT-SELENIUM ON PRODUCTION TRAITS IN YOUNG SIMMENTAL CATTLE UNDER THE CONDITIONS OF THE CARPATHIAN REGION OF BUKOVINA
}

\author{
Prylipko T.N. - Doctor of Agricultural Sciences, Professor, \\ Professor at the Department of Technology of Production, \\ Processing and Standardization of Livestock Products, \\ Podilsky State Agrarian and Technical University \\ Shulko O.P. - Candidate of Agricultural Sciences, Associate Professor, \\ Associate Professor at Biotechnology Department \\ Bila Tserkva National Agrarian University
}

The article presents the results of studies of productive performance of calves, diet digestibility and nitrogen metabolism, mineral elements in organism when using different selenium additives in their diets. Different selenium drugs did not significantly affect the feed intake of bulls of experimental groups. Every head in the control group consumed per day on average for $618 \mathrm{~g}$ of digestible protein, or $100 \mathrm{~g}$ per feed unit. And in the 1 st and 2 nd experimental groups, theconsumption was 617-619 g per 1 head, or $100 \mathrm{~g}$ per 1 fodder unit. The average daily gains of animals of 1st and 2-nd experimental groups exceeded the control, respectively, $67 \mathrm{~g}, 8.7 \%(P<0.05) ; 82 \mathrm{~g}$, or $10.8 \%(P<0.001)$. It is noted that the increase in the content of selenium in diet had a positive impact on the coefficients of digestibility of nutrients in animals of the experimental groups: dry matter of diet in the control group was digested by 67.8\%, whereas animals of the 1-2 test groups digested 71,3-72\%, which was by 5.1-6.1\% more; digestibility of crude fat in the control calves was by 56.2 per cent, in the experimental group it was by 9.3 to $10.2 \%(P<0.05)$ more. The highest coefficients of digestibility of crude fat were recorded in young bulls of the second test group receiving in diet supplement Devivit. Overall, the best results of digestibility of nutrients were obtained in the group of animals fed on diet containing drug Devivit. There was determined a positive effect of the studied supplements E-selenium and Devivit in diet on the metabolism of calcium, sulfur, zinc, copper and selenium.

Key words: animals, diet, selenium, digestibility, crude fat, dry matter, bulls, supplement nutrients, coefficient of digestibility of mineral elements, nitrogen balance.

Приліпко Т.Н., Шулько О.П. Вплив оптимальних рецептів раціонів на продуктивні показники молодняку симентальської породи за згодовування комплексного препарату "Девівіт-Селен" в умовах Карпатського регіону Буковини

У статті представлені результати досліджень продуктивності телят, засвоюваності раціону та метаболізму азоту, мінеральних елементів в організмі з використанням різних зеленовських добавок у своїх дієтах. Однак різні препарати селену не вплинули істотно на споживання кормів биків експериментальними групами. Кожна голова контрольної групи витрачала в середньому на добу 618 г перетравного протеїну, або 100 г на кормову одиницю. А в 1-й та 2-й експериментальних групах ијі витрати становили 617619 г на 1 голову, або ті ж 100 г на 1 кормову одиниџю. Середньодобовий приріст тварин 1-ї та 2-ї експериментальних груп перевищував контроль відповідно 67 г або 8,7\% $(P<0,05)$; 82 г або 10,8\% (P<0,001). Зазначається, щзо збільшення вмісту селену в раціоні позитивно вплинуло на коефіцієнти засвоюваності поживних речовин у тварин експериментальних груп: суху речовину раціону в контрольній групі засвоювали 67,8\%, тод $i$ як тварини 1-2 тестових груп 71,3-72\%, щчо на 5,1-6,1\% більше; засвоюваність сирого жиру в контрольних телят на 56,2\%, в експериментальних на 9,3-10,2\% (P<0,05) більше. Найвиі коефічієнти засвоюваності сирого жиру відзначали у бичків 2-ї тестовій групі, котра отримувала дієтичну селеноамінову добавку "Девт». Загалом, найкращі результати засвоюваності поживних речовин, отриманих у групі тварин, які мали в раціоні препарат «Девівіт». Установлено позитивний вплив досліджуваних добавок селановці «E-селен» $i$ «Девівіт» у раціоні на метаболізм кальцію, сірки, ичнку, міді та селену.

Ключові слова: тварини, дієта, селен, засвоюваність, сирий жир, суха речовина, поживні речовини, коефіцієнт засвоюваності мінеральних елементів, азотний баланс. 
Problem statement in general and its connection with important scientific and practical tasks. In the context of the global economic and financial crisis, domestic science has been enriched with data that allow us to argue that the further improvement of the quality of feeding of cattle as a whole, and of meat, in particular, should be related not so much to an increase in the rate of metabolism and nutrients in daily diet, how much with increasing its biological value, which is relevant in the Carpathian region of Bukovina.

Modern diet recipes for beef cattle cannot be imagined without proper trace elements. In the various countries of the world, the rations of this cattle are mostly added to the same trace elements and even at about the same doses. However, standards for the introduction of trace elements are periodically revised in the light of new developments in science and practice $[5 ; 8]$.

In recent years, studies have been intensified to determine the need for cattle in mineral elements, which were not previously taken into account in diets but have been shown to have a significant effect on the ruminant organism. Such elements and their compounds that attract the attention of scientists and experts in the field of beef cattle include selenium, which is recognized as an indispensable biotic ultramicroelement $[2 ; 7]$.

Numerous studies conducted on different species of animals have shown that selenium has antioxidant, immunostimulatory, anticarcinogenic, antimutagenic, adaptogenic, antiviral and radioprotective properties [6]. The discovery of the biological properties of selenium was the basis for its widespread use in feeding farm animals. The inclusion of selenium in the diet improves their health, increases the productivity and efficiency of feed use [1-4]. It has a significant effect on the absorption of vitamins A, C, E in the body, which are closely interconnected in the processes of metabolism.

However, when feeding livestock, the benefits of Vitamin E. are also beneficial. Being fat-soluble and chain-breaking, it protects cell membranes from being destroyed by lipid peroxide radicals. Vitamin $\mathrm{E}$ is actively absorbed in the gut: absorption depends on a number of factors, but averages up to $42 \%$ ( $\alpha$-tocopherol). But the use of these elements in feeding, particularly young animals, requires clear scientific justification [6].

Analysis of recent research and publications. The drug Devit-Selenium is used for the correction and normalization of metabolic processes in animals, but data on the use in feeding the meat of the Simmental are practically absent. In the composition of the new complex drug plays an important role trace element - selenium, which is involved in redox processes in the composition of enzymes glutathione peroxidase, phospholipid-glutathione peroxidase, oxidoreductase and some transferases. At the same time, vitamin $\mathrm{E}$, which is a natural antioxidant, plays an important role in its composition and is involved in preventing the processes of unsaturated fatty acid peroxidation (including cell membrane phospholipids), vitamins A and D, carotenoids, and the like. Deviten Selenium contains Lycopene, a naturally occurring carotenoid that does not have A-vitamin activity and has antioxidant, cytoprotective properties and is a promoter of tissue regeneration [6].

At the same time, for the creation of a new population in the Carpathian region of Bukovina ruminants of the ruminant with a pronounced natural lump of nutrients such as selenium and vitamin $\mathrm{E}$ are the most pressing issues.

Setting objectives. All of the above stipulates the need to develop and optimize the composition of the feeding rations of suckling young meat of Simmental in the stall period and to establish the efficiency of their use, taking into account the zonal features of the chemical composition of feed. 
The purpose of the work is to develop new dietary recipes for use in feeding complex drugs that are used for the correction and normalization of metabolic processes for suckling young beef meat during the growing period in the Carpathian region of Ukraine.

Materials and methods of study During the experiment, the conditions of care, feeding and retention of the experimental young were the same. The first stage of the work was the chemical analysis of feeds, on the basis of which the formulation of diets was developed. For the experiment, two groups of analogues (heifers and bugs) were formed, with 10 heads each. The initial live weight of the control groups was 57.6-61.8 kg, and the experimental weight was $58.9-59.6 \mathrm{~kg}$.

In the organization of feeding to the formulation of the diet in the main period of the experiment included: whole milk $-7.21-7.22 \mathrm{~kg}$, hay $-0.25-0.31 \mathrm{~kg}$, compound feed $-0.32-0.33 \mathrm{~kg}$. The diet contained: metabolic energy $-17.3-17.5 \mathrm{MJ}$, feed units $2.49-2.52 \mathrm{~kg}$, digestible protein $-218.5-228.3 \mathrm{~g}$, dry matter $-1.48-1.97 \mathrm{~kg}$, sugars 241-249 g, calcium - 15.2-15.7 g, phosphorus - 8.67-10.5 g. The diet of experimental animals included "Devit Selenium". The composition of the complex drug "Devit Selenium" was as follows: vitamin E (alpha-tocopherol acetate) - $50 \mathrm{mg}$, selenium (in the form of sodium selenite) $-0.5 \mathrm{mg}$, lycopene $-1 \mathrm{mg}$, filler - up to $1 \mathrm{ml}$. period of the experiment 60 days, the final - 30 days.

Research results. Differences in nutrient intake and consumption between the experimental groups were insignificant. In particular, the consumption of metabolic energy and dry matter per $100 \mathrm{~kg}$ of live weight in experimental heifers was $18.0 \mathrm{MJ}$ and $2.0 \mathrm{~kg}$ against $19.0 \mathrm{MJ}$ and $2.0 \mathrm{~kg}$ in the control group, whereas in the test group bugs they were slightly larger and were, respectively, 23.7 MJ and $2.77 \mathrm{~kg}$ against $21.8 \mathrm{MJ}$ and $2.90 \mathrm{~kg}$ in control. Expenditure of exchange energy per unit gain in experimental heifers was at 23.07 MJ versus $37.58 \mathrm{MJ}$ in the control group; in Bugayts they were respectively $21.1 \mathrm{MJ}$ versus $38.6 \mathrm{MJ}$.

The best payment for feed was also from the heifers of the experimental group and amounted to $3.32 \mathrm{pp}$, which is $0.51 \mathrm{pp}$. or $13.3 \%$ less than the peers of the control group, with feed costs per unit of increase in Bugayts $-3.04 \mathrm{cUd}$, which is $0.67 \mathrm{cUd}$. or $18.1 \%$ less than the control group.

Similarly, in the concentration of metabolic energy in one kilogram of dry matter of heifers of the experimental group by $20.5 \%$ and bugayka $-19.5 \%$ inferior peers of the control group.

In the course of the experiment it was found that during the main period of the experiment in heifers of the experimental group to which the drug was administered, the average daily increments were $750.1 \mathrm{~g}$, which is $100.0 \mathrm{~g}$ or $15.4 \%, \mathrm{P}<0.001$ more than the peers of the control group, which were on the farm feed without the introduction of drugs. Whereas the intensity of growth of bugs, which were administered the experimental drug during the main period of the experiment, was $830.2 \mathrm{~g}$, which is $150.1 \mathrm{~g}$ or $22.1 \%, \mathrm{P}<0.001$ more than the analogues of the control.

In the final period of the experiment, the average daily growth of calves in the experimental group was $870.2 \mathrm{~g}$, which is $230.1 \mathrm{~g}$ or $35.9 \%, \mathrm{P}<0.001$ more than the peers of the control group. In the Bugayi of the experimental group a similar indicator was higher than the control peers by $190.1 \mathrm{~g}$ or $25.0 \%, \mathrm{P}<0.001$.

Instead, for the whole period of the experiment in heifers of the experimental group, the average daily increments were $-800.3 \mathrm{~g}$, which is $150.1 \mathrm{~g}$ or $23.1 \%, \mathrm{P}<0.001$ more than the peers of the control group; $0 \mathrm{~g}$ or $53.4 \%, \mathrm{P}<0.001$.

At that, the live weight at the end of the final period in the experimental heifers was $124.8 \mathrm{~kg}$, which is $13.7 \mathrm{~kg}$ or $12.3 \%, \mathrm{P}<0.001$ more than the heifers of the control group. Meanwhile, the bugs of the experimental group had an average live weight of $132.3 \mathrm{~kg}$ 
Table 1

The live weight and increments of the experimental animals during the test period, $(M \pm m, n=10$ in each group)

\begin{tabular}{|c|c|c|c|c|}
\hline \multirow{2}{*}{ Indicator } & \multicolumn{4}{|c|}{ group } \\
\hline & \multicolumn{2}{|c|}{ control } & \multicolumn{2}{|c|}{ experimental } \\
\hline Number of animals, heads & bull & cow & bull & cow \\
\hline \multicolumn{5}{|c|}{ Live weight, kg: } \\
\hline to the beginning of the experiment & $61,8 \pm 1,20$ & $57,6 \pm 1,40$ & $59,6 \pm 1,50$ & $58,9 \pm 1,20$ \\
\hline at the end of the main experiment & $96,5 \pm 1,50$ & $90,5 \pm 1,30$ & $101,8 \pm 1,40$ & $97,0 \pm 1,20$ \\
\hline \multicolumn{5}{|c|}{ Increase: } \\
\hline total, $\mathrm{kg}$ & $34,7 \pm 0,87$ & $32,9 \pm 0,67$ & $42,2 \pm 0,75$ & $38,2 \pm 0,85$ \\
\hline daily average, $\mathrm{g}$ & $680,1 \pm 0,75$ & $650,1 \pm 0,65$ & $830,2 \pm 0,74$ & $750,1 \pm 0,57$ \\
\hline Feed costs per $1 \mathrm{~kg}$ increase, $\mathrm{k} . \mathrm{d}$. & 3,71 & 3,83 & 3,04 & 3,32 \\
\hline \multicolumn{5}{|c|}{ Live weight, kg: } \\
\hline at the end of the main experiment & $120,8 \pm 1,70$ & $111,1 \pm 2,10$ & $132,3 \pm 2,30$ & $124,8 \pm 1,60$ \\
\hline \multicolumn{5}{|c|}{ Increase: } \\
\hline total, $\mathrm{kg}$ & $24,3 \pm 0,56$ & $20,6 \pm 0,54$ & $30,5 \pm 0,55$ & $27,8 \pm 0,54$ \\
\hline daily average, $\mathrm{g}$ & $760,1 \pm 0,56$ & $640,1 \pm 0,45$ & $950,2 \pm 0,65$ & $870,2 \pm 0,75$ \\
\hline \multicolumn{5}{|c|}{ Increase for the whole period of experience: } \\
\hline total, $\mathrm{kg}$ & $47,5 \pm 0,57$ & $53,5 \pm 0,45$ & $72,7 \pm 0,64$ & $65,9 \pm 0,55$ \\
\hline daily average, $g$ & $580,1 \pm 0,45$ & $650,2 \pm 0,56$ & $890,1 \pm 0,65$ & $800,3 \pm 0,75$ \\
\hline
\end{tabular}

Note: *** $p<0.001$ - the probability of difference between the study groups over the control over the level of growth of live weight and live weight at the end of the final period.

in the final period, which is $11.5 \mathrm{~kg}$ or $9.5 \%$ more, $\mathrm{P}<0.001$ for control peers who were not administered the experimental preparation.

Analyzing the hematological parameters of blood of bugs of different breeds and their mixtures it can be observed that the level of hemoglobin and erythrocytes in experimental animals of all experimental groups was lowered at the beginning of the experiment.

It should be emphasized that hemoglobin in animals I, II, III-experimental groups was $89,0-90,0 \mathrm{~g} / 1$, in the 1-experimental was increased by $4,4 \%$, at the rate of $90-100 \mathrm{~g} / 1$. Erythrocytes, respectively, from -6.70 to $-6.90 \times 10.12 / 1$. at the rate of $6.70-70.00 \times$ 10 12./L. At the end of the experiment, these indicators stabilized, but more actively this process took place in calves 111 experimental group.

The leukocyte count was reduced in all groups and amounted to $3.50-6.80 \times 10.9$ / L. In this work it is shown that the number of the segment of nuclear neutrophils in Bugay at the end of the experiment decreased and amounted to $22.30 \%$ in the experimental group, in the control group $-18.25 \%$, respectively in heifers $21.5 \%$ and $21.60 \%$. Studies have shown that there have been changes in the composition of lymphocytes. In the blood of the bugs of the control group was $63.4 \%$, which is $6.7 \%$ more than experimental. Changes in the number of monocytes in animals of the experimental $9.2 \%$, which is more than $2.4 \%$ of the control, were detected above the norm. Studies have shown that the blood of animals in the experimental group III contained more than $0.10-0.24 \mathrm{mln} . \mathrm{mm}$ of erythrocytes, $0.16-0.3 \mathrm{~g} \%$ hemoglobin 0.240 and $0.33 \%$ protein. However, in the blood of animals of the third group was slightly higher alkaline reserve and carotene content. For the rest of the blood indices, no differences were observed in the individual animal groups.

At the same time there was a decrease in the proportion of the nuclear neutrophil segment: in heifers at $21.5 \%$, in bugs - by $4.05 \%$. At the same time, the decrease in the pro- 
portion of nuclear neutrophils in the blood was accompanied by an increase in the level of lymphocytes, and the difference between the experimental group and the control was $1.8 \%$ and $4.8 \%$, respectively. Monocytes in the amount of $2.80-3.20 \%$ were detected in the blood of the experimental groups and $2.60-2.74 \%$ in the blood of the control animals. The proportion of basophils peers differed little from each other. However, it should be noted that from the neutrophil group of granulocytes, myelocytes were not detected in any of the groups.

No significant differences were found between the young groups of the morphological blood composition groups.

However, in the young of the experimental group, the main indicators studied were slightly higher. Thus, in the blood of heifers and bugs treated with the experimental drug, there was a higher number of erythrocytes by 6.5 and $4.7 \%$ and hemoglobin concentration, respectively - by 3.9 and $8.7 \%$. Quantitative changes in the number of leukocytes were absent, since their content in the blood of young experimental and control groups was approximately the same level.

As a result of laboratory studies of the samples, it was found that the biochemical parameters of serum, protein and mineral metabolism in suckling young were within the age of physiological norm. However, in the nature of changes in hematopoiesis, there were some differences that depended on the effect on the organism of animals of different feeding conditions.

Inclusionin the diet of the experimental groups of animals of the experimental drug promoted their biological value and improved the course of metabolic processes in their body. In particular, heifers and cougars of the experimental groups were found to have a clear difference in serum total protein content by 10.4 and $12.3 \%, \mathrm{P}<0.05-\mathrm{P}<0.001$.

At the same time, the increase of serum protein content in the experimental groups was not only due to albumins (by 11.4 and 16.4\%, respectively), but also due to the increase of globulin accumulation - by 5.8 and $10.3 \%$, respectively. First of all, the gamma-globulin fraction was markedly distinguished among the latter, indicators of which were higher than the control groups by $4.0 \%$ and $7.4 \%$ respectively.

The use of the drug had no significant effect on the nature of changes in the mineral and biochemical composition of blood of young experimental groups compared with the control. However, the tendency for their superiority over the peers of the control group remained: in the content of total calcium - by 2.0 and $2.4 \%$; inorganic phosphorus by 4.2 and $12.5 \%$; alanine and aspartate aminotransferase enzymes by 6.7 and $10.5 \%$ and 4.9 and $9.7 \%$ respectively, alkaline phosphatase activity by 2.2 and $3.7 \%$.

Conducted economic analysis of the data research on the basis of existing prices for beef in live weight, cost of feed and other production costs. Noteworthy in our studies that the best economic indicators obtained in the experimental group of calves, where the feed costs per $1 \mathrm{~kg}$ of gain in live weight made up $3.04 \mathrm{C}$. K. units, the cost of gain in live weight of 1 head for the cultivation period was $1150 \mathrm{UAH}$. Net income per 1 head in this study group was the highest and amounted to UAH 2 544,5. As a result, the profitability of cultivation were respectively 17.0 per cent. Below, several economic indicators obtained for fattening steers in the control group. So, cost of feed per $1 \mathrm{~kg}$ increase of live weight of 1 head was to $3.71 \mathrm{p}$. K. units, and the cost of 1 quintal of live weight gain of $1150 \mathrm{UAH}$. with a net gain of $1 \mathrm{~kg}$ live weight 1662,5 . with a margin of $11.1 \%$.

Thus, it was found that the net profit per head in this group was the highest and amounted to $2544.5 \mathrm{UAH}$, with a profitability $-17.0 \%$, while similar indicators of growing experimental heifers were accordingly - $2306.5 \mathrm{UAH}$. and $15.0 \%$, which ensures the development of its own inexpensive technology for feeding ruminant Simmental ruminant economically promising in the region of Bukovina region. 
Conclusions. It was found that during the main period of the experiment in the heifers of the experimental group to which the drug was administered, the average daily increments were $750.1 \mathrm{~g}$, which is $100.0 \mathrm{~g}$ or $15.4 \%, \mathrm{P}<0.01$ more than the peers of the control group, which were on the farm feed without the introduction of drugs. While the growth rate of bugs administered the test drug during the main experimental period was $830.2 \mathrm{~g}$, which is $150.1 \mathrm{~g}$ or $22.1 \%, \mathrm{P}<0.001$ more than the control analogs.

It was determined that the best payment for feed production was also in heifers of the experimental group and amounted to 3.32 feed units, which is 0.51 feed units. or $13.3 \%$ less than the peers of the control group, with feed costs per unit of increase in Bugayts -3.04 feed units, which is 0.67 feed units. or $18.1 \%$ also less than the control group with the concentration of metabolic energy in one kilogram of dry matter of the calf of the experimental group by $20.5 \%$ and the cougar $-19.5 \%$ inferior to the peers of the control group.

Studies have shown that the blood of heifers and bugs treated with the experimental drug increased the number of erythrocytes by 6.5 and $4.7 \%$, hemoglobin concentration - by 3.9 and $8.7 \%$, total protein content - by 10,4 and $12.3 \%$, albumin - by 11.4 and $16.4 \%$, total calcium - by 2.0 and $2.4 \%$; inorganic phosphorus - by 4.2 and $12.5 \%$; alanine and aspartate aminotransferase enzymes by 6.7 and 10.5 and 4.9 and $9.7 \%$ respectively, alkaline phosphatase activity by 2.2 and $3.7 \%$, respectively, compared with the control group.

\section{REFERENCES:}

1. Морфо-біохімічні показники крові та репродуктивної якості свиноматок під дією кормової добавки "PROPIGplv" / Й. Півторак, вівторок, I.М. Бліда. Науково-технічні науки. bul.science.-експеримент. Центр біобезпеки та екологічного контролю ресурсів АПК. Дніпропетровськ, 2016. Т. 4, № 1. С. 41-46.

2. Калинка А.К. Вплив брикетів на інтенсивність приросту м'ясного запасу символіки тварин в умовах Буковини. 3б. наук. “YOGO” праџює з міжнародними матеріалами. Конф. «Наукові новини: До 20-ї річниці розведення нової популяиії м'ясо-сименталів на Буковині», Чернівиі, 10 серпня 2019 р. / за заг. ред. А.К. Калінки. Чернівці : ГО «Європейська наукова платформа», 2019. С. 58-61.

3. Вплив годівлі БВМД «Енервік» на якість свинини / В.В. Білявцева, Н.В. Гуцол. Збірник звітів всеукраӥнський. Конф. Екологічні проблеми сільського виробництва (Вінниця, 7 грудня 2016 р.). Вінниця, 2016. С. 140-141.

4. Вплив різних рецептів годівлі дієт нової телячої популяції на продуктивність в передгір'ї Карпатського регіону Буковини / А.К. Калинка. Зб. наук. "YOGO" npaцює з міжнародними матеріалами. Конф. «Наукові новини: До 20-ї річниці розведення нової популяиії м'ясо-сименталів на Буковині», Чернівиі, 10 серпня 2019 р. $/$ за заг. ред. А.К. Калінки. Чернівці : ГО «Європейська наукова платформа». 2019. С. $55-58$.

5. Prylipko T.M, Kostash VB, Zakharchuk PB, Lishchuk SG Selenium content in the diets of dairy cattle in the Podillya zone of Ukraine Proceedings of the International Scientific Conference "International Trends in Science and Technology" (October 17, 2017, Warsaw, Poland). P. 48-52.

6. Prylipko T., Bukalova N., Lyasota V Features of the introduction of the HACCP system on enterprises of Ukraine. The potential of modern scienct. London, 2019. Volume 1. P. 49-60.

7. Біоморфологічна організація та живлення кормів : монографія / В.І. Гноевий, А.К. Тришин, І.В. Пус ; ред. проф. ВАМ. Харків : ФЛП Бровін А.В., 2017. 560 с.

8. Prylìpko, T.M., Prylìpko, 1.V. Task and priorities of public policy of Ukraine in food safety industries and international normative legal bases of food safety. Proceedings of the International Academic Congress "European Research Area: Status, Problems and Prospects" (Latvian Republic, Riga, 01-02 September 2016). 